\title{
Equality, Did You Say?
}

Chinese feminism after 30 years of reforms

Tania Angeloff and Marylène Lieber

Translator. N. Jayaram

\section{(2) OpenEdition}

\section{Journals}

\section{Electronic version}

URL: http://journals.openedition.org/chinaperspectives/6014

DOI: 10.4000/chinaperspectives.6014

ISSN: 1996-4617

\section{Publisher}

Centre d'étude français sur la Chine contemporaine

\section{Printed version}

Date of publication: 7 December 2012

Number of pages: $17-24$

ISSN: 2070-3449

\section{Electronic reference}

Tania Angeloff and Marylène Lieber, « Equality, Did You Say? », China Perspectives [Online], 2012/4 |

2012, Online since 01 December 2015, connection on 28 October 2019. URL : http://

journals.openedition.org/chinaperspectives/6014 ; DOI : 10.4000/chinaperspectives.6014 


\title{
Equality, Did You Say?
}

\section{Chinese feminism after 30 years of reforms}

\author{
TANIA ANGELOFF AND MARYLĖNE LIEBER
}

\begin{abstract}
After 30 years of economic reforms, what is the comparative situation of men and women in the People's Republic of China? How can we analyse the policies for promoting gender equality? Have inequalities that existed in Mao's China disappeared now? Or have factors such as the liberalisation of the labour market and the single child policy merely shifted the boundaries of such inequalities and even created others? This article looks at the ways in which the equality issue is dealt with, both by the government and by the All China Women's Federation and feminist organisations. It seeks to show which inequalities are prioritised and what has been the state's place in contemporary Chinese feminism.
\end{abstract}

KEYWORDS: feminism, state feminism, women's rights, equality between the sexes.

F or almost a century, equality between men and women has been a recurring theme in political, economic, and social discussions in China. In the early twentieth century, it was invoked in pioneering reformers' discourses on Chinese modernity, and was seized on with the formation of the Communist Party of China in 1921. Up until the end of the Cultural Revolution and Mao Zedong's death, it seemed to be a frequently asserted concern in mass campaigns launched through the People's Daily and the powerful All China Women's Federation (ACWF).

This article seeks to take stock of the handling of equality between men and women in China after 30 years of reforms and at a point when China has emerged as the world's second largest economy. Economic reforms opened the path to liberalisation, creating the impression of under-emphasis on socialist ideology and thus on talk of social equality as well as equality between the sexes. But the situation is more nuanced than it would appear with regard to the two periods - before and after the reforms. On the one hand, the Maoist state had discriminatory practices when it came to jobs for women, often disregarding official discourse ${ }^{(1)}$ to lay them off or offer them only intermittent work, as during the Great Leap Forward (1959-1961) and the Cultural Revolution (1965-1968). On the other hand, in recent times, even under a liberalised economy, the Chinese regime deems itself to be a people's democratic dictatorship, and political actors remain focused on social issues, including the inequality between the sexes. In this context, the question arises as to how these inequalities are handled. What concrete actions have been taken by the government, the ACWF, and women's associations that have proliferated since the Fourth World Conference on Women (Beijing, 1995)? Further, what role does the ACWF play today, and what can we make of Chinese feminism?

Feminism is widely defined as a current of thought favouring women's rights and the elimination of inequalities between men and women and also, more recently, among women themselves. It is manifested in state organs as well as in civil society (associations and non-governmental organisations), thus creating what Laure Bereni terms the "women's cause arena." (2) In China's case, given the stranglehold of the heavily state-dependent ACWF, there is talk of "state feminism," which prevailed at least until Mao's death in 1976, (3) and in some feminists' eyes, persisted afterwards. (4)
While the term "state feminism" generally refers to a particular segment of actions in support of women's causes, in China's case, it could suggest that there is as yet little or no room for feminist movements outside of the governmental framework. The real situation is more complex. The institutional existence of a women's organisation constitutes an impressive arena for some feminists to make their voices heard, and moreover, the government's own quest for equality has also helped the development of other NGOs and active women's rights networks from the mid-1990s onward.

This article tackles the issue of the expressions and challenges of contemporary Chinese feminists, looking into the social reality of inequalities between the sexes as well as the concrete actions taken to counter them. The first part of the article presents a rapid assessment of the inequalities between men and women, and the second examines concrete actions and programmes the Chinese government has adopted since the 1990s. The third and last part looks into the Chinese state's legitimacy and monopoly in matters of equality and into the quest for women's and feminists' autonomy, presenting a few profiles of prominent Chinese feminists.

\section{Equality between men and women: Some elements for consideration}

Although the principle of equality of men and women has figured in the Constitution since 1950, it remains far from being realised. In all major activities and junctures of life - birth, family, marriage, education, employment, political participation, salary, old age, or illness - Chinese women

1. Tang Xiaojing, "Les femmes du Grand Bond en avant. Miroirs et masques idéologiques" (Women of the Great Leap Forward: Ideological mirrors and masks), Travail, genre et societies (Work, gender and societies), No. 24, pp. 61-78

2. Laure Bereni, "Penser la transversalité des mobilisations féministes: l'espace de la cause des femmes" (Towards transversality of feminist mobilisations: The women's cause arena"), in C. Bard (ed.), Les féministes de la deuxième vague (Feminists of the second wave), Rennes, Presses Universitaires de Rennes, 2012.

3. Wu Xiaoying, "From State Dominance to Market Orientation: The Composition and Evolution of Gender discourse," Social Sciences in China, special issue "Social Change and Chinese Women," Vol. XXXI, No. 2, 2010, pp. 150-164

4. Wang Zheng, "'State Feminism'? Gender and Socialist State Formation in Maoist China," Feminist Studies, No. 31, 2005, pp. 519-551. 
suffer numerous forms of discrimination, overt or covert. (5) Isabelle Attané has drawn attention to the alarming demographic situation - there are now 108 males for every 100 females, an undeniable sign of persisting inequality between the sexes. ${ }^{(6)}$

The move from a planned to a market economy had significant consequences on the evolution of inequalities between the sexes. While the Maoist state (1949-1976) sought - at least in official discourse and employment policy - to eradicate inequalities between men and women and their adherence to pre-communist traditions, the reform and opening policies adopted in the late 1970s were largely built on the traditional representations of women's role in the family and in society. ${ }^{(7)}$ While the stress on economic modernisation since the early 1980s as a development project as well as social intervention helped some categories of women, especially in urban areas, to improve their status, it has bypassed a major section of the population. China's unprecedented economic development was possible thanks to institutionalised discrimination against migrant men and women from rural areas and the employment of young women from rural areas in southern China's export industries. ${ }^{(8)}$

It is impossible to compare the two periods in isolation, as discussion may be confined to whether economic reforms introduced in the late 1970s contributed to attenuating or reinforcing pre-existing inequalities - albeit denied by socialist ideology. (9) Nevertheless, gender inequality and discrimination persisting within families, education, employment, and politics among others still needs to be exposed, as does the way in which inequalities have been treated in institutional and activist debates.

The one-child policy adopted at the end of the 1970s resulted in an aggravation of the demographic imbalance. Forced to have just one baby, most couples chose to settle for sons and ensure continuity through a male successor. The resulting shortage of females leads the "excess" males to forced celibacy, as well as to a growth in trafficking in women and violence against them. And although education is seen as the spearhead of China's development, in both policies as well as official discourse, the preference for sons results in germs of discrimination with regard to schooling. Some real progress has indeed occurred in the field of education, but disparities persist and have worsened to the detriment of girls, especially among the most neglected sections of the population. ${ }^{(11)}$

In the context of economic liberalisation and with skewed demographics, the field of employment domain displays inequalities more prominently than others: overt discrimination in recruiting, marked gender division at work, salary differences, massive layoffs of female employees in state enterprises right from the 1990s onward, ${ }^{11}$ harsh treatment of migrant workers, low participation of women in politics, and a rise in sex work, which had been fought during the socialist period. As for women's work and employment, numerous ethnographic investigations and studies highlight new frontiers of inequality between the sexes. New because they are not based entirely on gender difference - a hierarchy whose existence was denied by the ideology of the 1950-1970 decades. Rather, gender, socioeconomic category, age, and ethnicity (with marked differences between urban and rural origin) are enmeshed in an intersectional logic that was less obvious when class struggle suppressed all other forms of inequality in official discourse.

Briefly, equality between men and women is far from having been achieved. The Chinese government is aware of the distance to be traversed in this regard, and it has legislated since the mid-1980s on women's rights, launching several action programmes to promote equality between the sexes.

\section{Development of a legislative arsenal and action programmes (1985-2011)}

Social relations between the sexes have long constituted a structural element in Chinese modernity, ${ }^{(12)}$ and were reconfirmed in post-reform governmental policies in the matter of equality between women and men. Whereas any feminist demand was deemed bourgeois during the Cultural Revolution (social relations between the sexes then took second place to duty towards the country and socialism), the 1980s and 1990s witnessed a sea change, with a reaffirmation of women's rights as an essential element in human rights and with major legislative developments in regard to equality between the sexes.

It was in this period that the Chinese government, realising the importance for a modern great power to adhere to international principles, began developing the rhetoric of rule of law (yi fa zhi guo) and acquiring a set of legislation. ${ }^{(13)}$ In the same vein, it relied on international laws in order to build national laws in respect of equality between women and men. The period prior to the Cultural Revolution had set major milestones, such as the 1950 promulgation of the first law on marriage, stipulating monogamy, union through mutual consent, and equality between the spouses in the household. In its initial years, the Maoist government sought to break with previous practices by promoting class liberation and everyone's subservience to the state, and so in effect was committed to according equal rights to women and men.

While the post-reform government retained this basic position on the issue of equality between the sexes, post-1990s laws have taken a novel turn. From the 1990s, when Beijing hosted the Fourth World Conference on Women, China really began legislating on rights of women as individuals - not merely as members of a collective entity as during the pre-reform era. As this extract from a document published by the State Council Information Office stated in June 1994:

Women are actively plunging into China's social development as masters of society, becoming a great force in both economic construction and cultural and ideological advances. They are a vital force in China's reform and opening to the outside world and the mod-

5. On this point, see Tania Angeloff, Histoire de la société chinoise (History of Chinese society), Paris, La Découverte, 2010; Laurel Bossen, "Missing Girls, Land and Population Controls in Rural China," in Isabelle Attané, Christophe Guilmoto (ed.), Watering the Neighbour's Garden: The Growing Demographic Female Deficit in Asia, Paris, CICRED, 2007, pp. 207-228.

6. See Isabelle Attané's article in this issue.

7. Margery Wolf, Revolution Postponed: Women in Contemporary China, Stanford (CA), Stanford University Press, 1985.

8. Lee Ching-Kwan, Gender and the South China Miracle:Two Worlds of Factory Women, Berkeley/Los Angeles/London, University of California Press, 1998.

9. Tania Angeloff, "La Chine au travail (1980-2009): emploi, genre et migrations" (China at work: Jobs, gender and migration), Travail, genre et societies (Work, gender and societies), No. 23, 2010, pp. 79-102.

10. Amandine Monteil, "Éducation: la longue marche des Chinoises" (Education: Chinese girls' and women's long march), in Tania Angeloff and Marylène Lieber (eds.), Chinoises au xxie siècle: entre ruptures et continuities (Chinese women in the twenty-first century: Between gaps and continuity), Paris, La Découverte, 2012, pp. 43-62.

11. Tang Xiaojing, Femmes au foyer, filles de fer et retour au foyer. Genre et travail à Shanghai sur quatre générations 1949-2007 (Housewives, iron women, and back to housewife status: Four generations of gender and work in Shanghai), PhD dissertation, Paris, EHESS-ENS, 2009; Tania Angeloff, "Le féminisme en République populaire de Chine: entre ruptures et continuités" (Feminism in People's Republic of China: Between gaps and continuity), Revue Tiers Monde (Third World Review), No. 209, 2012, pp. 89-105.

12. Wu Xiaoying, "From State Dominance to Market Orientation," art. cit.

13. Susanne Brandtstädter, "The Law Cuts Both Ways: Rural Legal Activism and Citizenship Struggle in Neosocialist China," Economy and Society, Vol. 40, No. 2, 2011, p. 266-288. 
ernisation drive. Women have made extremely important contributions in various undertakings, including industrial and agricultural production, science, culture, education, and health care. In China, the expression "women hold up half the sky" has become the most vivid expression the entire society uses to praise the role played by women.

While women's impetus for social development has been forming, great changes have taken place in their mental outlook. They have gained a sense of self-respect, self-confidence, self-reliance, and selfstrengthening and have taken long strides forward in their ability to participate in government and political affairs, in their cultural accomplishment, level of scientific knowledge, and production skills. ${ }^{(14)}$

This affirmation of "four selfs" was among new elements in formulating the Law for protecting women's rights and interests, first adopted in 1992 and revised in 2005 (Funü quanyi baoxian fa). The right to self-respect, selfconfidence, self-reliance, and self-strengthening reflects a new understanding of "modernisation" that spread in this period, stressing the creation of quality citizens (suzhi). ${ }^{(15)}$ The stress is on Chinese women's participation in national construction, while learning to do so autonomously and individually, and acquiring necessary competences for adapting and participating in the market economy. ${ }^{(16)}$ This ideology represents a new sense of law in China: both before and after 1949, what had prevailed was not liberal thinking aimed at freeing individuals from their yokes. Rather, the aim was to develop laws to ensure that citizens transformed themselves for promoting China's progress, advancement, and homogenisation. (17)

In the past two decades, the government has passed many laws to promote and protect women's rights in the political, social, cultural, and economic realms, in order to turn them into modern and autonomous citizens (see Table 1). Now Chinese women benefit from a major legislative arsenal for protecting their rights, although that hardly means discrimination has ceased, as stressed earlier. In order to promote the application of laws and at the same time usher in a modern state devoid of "feudal" practices, the government launched campaigns from 1995 onwards to foster the development of the rights of women and girls.

All these official initiatives at the individual level reflect the importance China's government attaches to the issue, all the more so as violations of women's rights have occurred regularly in the post-reform period. Women's status is deemed representative of that of all citizens; it indicates the nation's condition as a whole. ${ }^{(18)}$

\section{Three action programmes for development of women's rights}

The Fourth World Conference on Women in Beijing in September 1995, with a parallel NGO conference held in Huairou, marked a new stage in the sense that it was followed by the launch of China's first action programme for women's development, incorporating major themes of the platform of action adopted at the conference (zhongguo funü fazhan gangyao). ${ }^{(19)}$ This programme was promoted by the National Working Committee on Children and Women under the State Council, which had been set up in 1990, ${ }^{(20)}$ for coordination and consultation in order to ensure that all provincial governments adapted it to local situations. (21)

At the national level, the first action programme aimed to 1) strengthen women's participation in decision-making and management of public af-

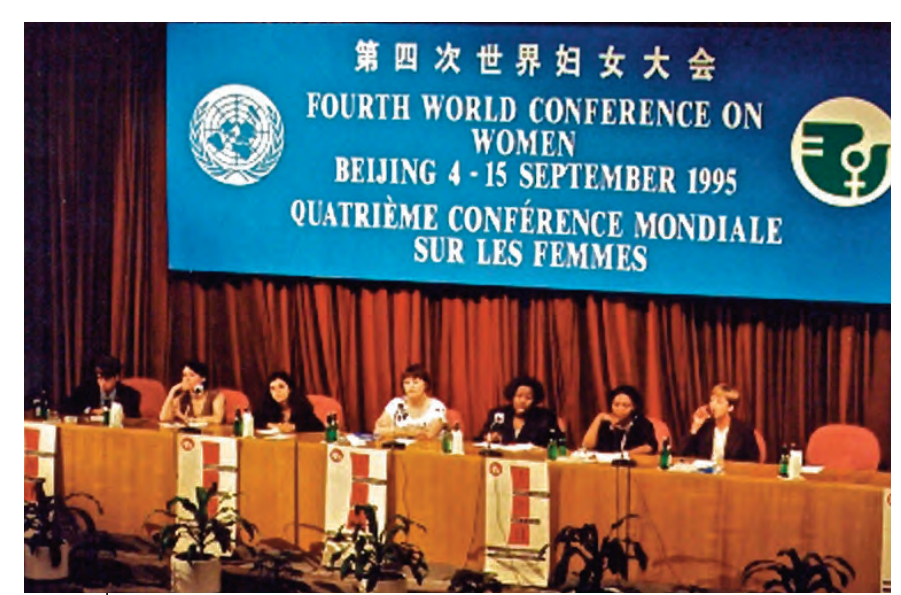

Youth delegates attending the Fourth World Conference on Women in Beijing, China on 9 September 1995. ๑ UN/DPI 090214/M. Grant

fairs; 2) promote the organising of women and their active participation in reforms so as to build a modern society and develop their competitiveness; 3) guarantee women's right to work; 4) promote women's education and improve their scientific and cultural levels; 5) improve women's health with guaranteed access to family planning; 6) promote "harmonious" and egalitarian families; 7 ) eradicate violence against women; 8 ) help promote women from the poorest regions and minorities; 9 ) improve women's social environment and quality of life; 10) foster exchanges with women of all countries to promote world peace; 11) set up a data collection system to chart changes in women's status. Among these 11 objectives, divided into eight action sectors, ${ }^{(22)}$ pride of place went to women's development in the poorest rural regions ${ }^{(23)}$ - especially with the creation of a microcredit project for women, (24) as well as the combating of violence against women. (25)

14. Extrait de la déclaration du bureau d'information du conseil des Affaires d'État de juin 1994, voir "The Situation of Chinese Women," www.nwccw.gov.cn/?action-viewnews-itemid-140654 (consulted on 25 September 2012).

15. Tamara Jacka, "Cultivating Citizens: Suzhi (Quality) Discourse in the PRC," Positions, Vol. 17, No. 3, 2009, pp. 523-535.

16. Wu Xiaoying, "From State Dominance to Market Orientation," art. cit.

17. Susanne Brandtstädter, "The Law Cuts Both Ways...," art. cit.

18. Tong Xin, "Mainstream Discourse and the Construction of Public Understanding of Women's Employment," Social Science in China, Vol. XXXI, No. 2, 2010, pp. 135-149.

19. Programme for the development of Chinese women, 1995-2000, Beijing, State Council, 1995, www.un.org/esa/documents/ga/conf177/natrep/china/nap1997-china.htm (consulted on 7 May 2012).

20. The head of this commission is a member of the ACWF.

21. This committee is headed by the State Council vice-chairman and consists of 33 delegates drawn from ministries, commissions, or "associations" such as the ACWF. Each province, region, and autonomous municipality has a committee under local authorities' supervision.

22. 1) Taking political decisions; 2) employment and job protection; 3) education; 4) health; 5) family planning; 6) legal aid; 7) social environment and women's development; 8) poverty. State Council, Programme for the development of Chinese women, 1995-2000, op. cit.

23. Tamara Jacka and Sally Sargeson, Women, Gender and Rural Development in China, Cheltenham (Britain), Edward Elgard Publishing, 2011.

24. See for instance Zhang Hong, Feng Yuan, Marylène Lieber, Yang Xiaoning, Xu Xiaopeng, Bai Minchun, and Wang Yanchun, Fupin yu funü canyu fazhan: dui nei menggu liang ge cunzhuang de shehui xingbie diaocha (Poverty alleviation and women in development: A gender case-study on two villages in Inner Mongolia), 2000, Beijing, UNDP.

25. Tan Lin, "Quel Statut pour les femmes chinoises?" (What status for Chinese women?), in Isabelle Attané (ed.), La Chine au seuil du XXle siècle. Questions de population, questions de société (China at the turn of the twenty-first century: Issues of population and society), Paris, Ined, 2002, pp. 329-348. 
Table 1 - Chinese laws promoting equality between the sexes since 1949

\section{0 - Law on marriage}

1954 - Constitution incorporates the principle of equality between women and men

1980 - Second law on marriage

1982 - Constitutional amendment stipulating equality between the sexes (women's right to participate in political, economic, and family decisions).

1983 - China ratifies CEDAW - second marriage law amended

1985 - Law on succession granting equal rights to women and men

1986 - Law on universal compulsory education; regulations on women's employment and care of infants

1988 - Regulations on women's employment: protection of workers and employees during pregnancy

1990 - Formation of a National Working Committee on Children and Women under the State Council

1992 - Law on protection of rights and interests of women

1994 - 1950 - Law on marriage

1954 - Constitution incorporates the principle of equality between women and men

1980 - Second law on marriage

1982 - Constitutional amendment stipulating equality between the sexes (women's right to participate in political, economic, and family decisions).

1983 - China ratifies CEDAW - second marriage law amended

1985 - Law on succession granting equal rights to women and men

1986 - Law on universal compulsory education; regulations on women's employment and care of infants

1988 - Regulations on women's employment: protection of workers and employees during pregnancy

1990 - Formation of a National Working Committee on Children and Women under the State Council

1992 - Law on protection of rights and interests of women

1994 - Employment law, with mention of the principle of nondiscrimination against women; passage of law on health of mothers and children

1994 - Prohibition of sex-selective abortion

1995 - Fourth World Conference on Women in Beijing; publication of first programme of action (1995-2000) for women's development in China

2001 - Amendment of marriage law (outlawing bigamy and domestic violence); launch of second programme of action (2001-2010) for women's development in China.

2002 - Law on population and family planning (specially reiterating ban on selective abortions)

2003 - Launch of campaign to "Care for girls"

2005 - Revision of law on protection of women's rights and interests

2008 - Law on job promotion; contract labour law; law on rural land use

2011 - Launch of third programme of action (2011-2020) for women's development in China
To mark the fifth anniversary of the World Conference on Women, the Chinese Women's Research Society (Zhongguo funü yanjiuhui), with UN Women's backing, organised a symposium in Beijing in May 2000 to take stock of the first action programme's functioning. It was then noted, despite the Chinese government's reluctance to say so officially, ${ }^{(26)}$ that reforms had contributed significantly towards accentuating discrimination against women - especially girls - and in terms of women's joblessness and rising domestic violence. ${ }^{(27)}$

It was then that the State Council launched the second programme for women's development, ${ }^{(28)}$ specially invoking the UN Millennium Development Goals, which sought among other things to promote education for all, non-discrimination against women, and greater attention to the health of mothers and infants. This programme for the $2001-2010$ period had similar goals but focused on six major themes accompanied by a systematic set of specific objectives, policy measures to be taken, and laws to be passed, revised, or better applied: 1) the economy, 2) decision-making in terms of policies and administration, 3) education, 4) health, 5) laws, and 6) environment. (29)

The second programme differed somewhat from the first in that it laid greater stress on "mainstreaming" as recommended by international organisations, that is to say, integrating the gender relations dimension into each stage of the policy-making process; it moved away from the collective discourse that characterised the first programme. Thus, while in 1995 the talk was of improving women's conditions "because women's status reflects the quality of the nation as a whole," (30) the programme launched in 2001 laid greater stress on the state's "responsibility" to protect women's rights and interests, although it did go on to "encourage women to strive harder and fight for a better status by participating in the country's economic and social development." (31)

In 2004, following the $23^{\text {rd }}$ session of the UN General Assembly on the challenges faced by women around the world, (32) the National Working Committee on Children and Women presented its first official report on the development of policies in respect of gender equality in China. Albeit adopting a positive official tone, it did not hide the difficulties in applying programme goals efficiently and uniformly in the domains of employment, education, health, and political participation of rural women. It stressed the need for greater coordination among working committees for women and children at various administrative levels.

In 2006, ACWF published a green paper discussing the advancement of women's rights and offering an evaluation of their status over the ten years since the Beijing conference and the launch of the first programme for women's development. ${ }^{(33)}$ It analysed differences among provinces, municipalities, and autonomous regions in matters of education, health, employ-

26. Programme for the development of Chinese women, 2001-2010, Beijing, State Council, 2001, p. 2. See "The Program for the Development of Chinese Women (2001-2010)," www.nwccw.gov.cn/ ?action-viewnews-itemid-140651 (consulted on 25 September 2012).

27. Tan Lin, "Quel Statut pour les femmes chinoises?", art. cit.

28. Programme for the development of Chinese women, 2001-2010, op. cit

29. Ibid.

30. State Council, Programme for the development of Chinese women, 1995-2000, op. cit., p. 2

31. Programme for the development of Chinese women, 2001-2010, op. cit., p. 2

32. "Women 2000: Gender equality, development and peace for the twenty-first century," held in 2000 in New York and also referred to as "Beijing + 5."

33. ACWF, Zhongguo xingbie pingdeng yu funü fazhan baogao (Zhongguo funü lüpi shu) (China Gender Equality and Women's Development Report [Green paper on Chinese women]), Beijing, Social Sciences Academic Press, 2006 
ment, family, environment, and political participation. While the paper noted a general improvement in women's status, it nevertheless pointed out the persistence of some forms of discrimination as well as of domestic violence. ${ }^{(34)}$ This green paper was followed in 2009 by another ${ }^{(35)}$, this time on the most vulnerable women such as migrants, the unemployed, those left behind in the countryside, the aged, and the handicapped. ${ }^{(36)}$ The papers made systematic recommendations for improving measures to protect women and girls and commended amendments to the law on protecting women's rights and interests in 2005 as well as decrees on implementation in some provinces.

More recently, in 2011, the third action programme for women's development followed, and as in 2001, a parallel one for children was launched as well. It covered the same ground as in 2001 , stressing persistent discrimination especially due to the development of market economy and international competition. Divided into seven major recurring themes (health, education, political participation, social security, environment, and judicial protection), it set new goals for the decade: developing women's participation at all political levels (by fixing quotas) and boosting access to jobs. The programme also reiterated the need to ensure access for all, irrespective of regional origin, to maternity insurance and basic health. ${ }^{(37)}$

\section{The "Care for girls" campaign, or the emergence of a differentialist viewpoint}

These three action programmes have been accompanied by other initiatives for women's protection. One such is the "Care for girls" campaign (guan ai nü'er) officially launched in 2003, after a test period, to try and restore the balance in the sex ratio among the young in Chinese society. ${ }^{(38)}$ In order to counter son preference, which became acute after economic reforms and the rapid march towards a market economy, the government launched a campaign in rural areas to promote equality between the sexes by promoting the girl child's status. The results have been patchy, and Lisa Eklund says that despite the critical dimension, especially as regards institutions favouring son preference, such as patrilocal marriage, the campaign includes no programme to challenge this institution. ${ }^{(39)}$ As in the case of action programmes for women's development that never discuss discrimination linked to the residence permit (hukou), which is largely to blame for discrimination against women from rural areas, these measures are at pains to challenge widespread discriminatory practices. Eklund further notes that although it has noble aims, the campaign rests on gender representations such as showing girls to be more loving and gentle and closer to their parents. While in the short term such arguments may promote girl child preference, in the long run they will only reinforce the idea of supposed natural differences between women and men.

Action programmes for women's development and rights, as well as campaigns for promoting equality between the sexes, no doubt aim for a general improvement of women's rights, but what stands out is also the new differentialist ideology that characterised post-Maoism in China. ${ }^{(40)}$ While it is important to legislate for promoting the development of autonomous individuals capable of adapting to the market economy, women's rights will gradually be associated with those of children in line with the action programmes, thus implicitly reaffirming an alleged difference in nature or feminine specificity. Grouping women with children not only underlines the fragility associated with these two demographic groups, but also adds to a naturalist vision of relationships and of women's social roles. ${ }^{(41)}$

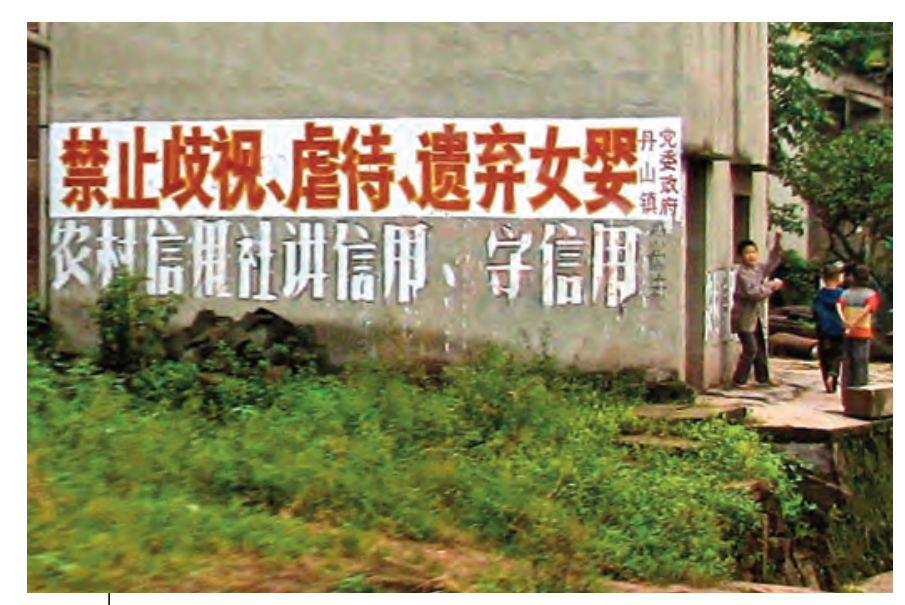

The red roadside sign reads: "It is forbidden to discriminate against, mistreat, or abandon baby girls," as part of a Sichuan Party Committee and government campaign in Danshan Township, September 2005.

๑ David Cowhig/Wikipedia

This differentialist ideology is widespread in China now, with naturalisation of gender roles hardly being questioned. In the current consumer society, femininity is highlighted through a panegyric to beauty and gentleness, along with talk of the need for women to return to the household, so as to focus on what is presented as their natural role. ${ }^{(42)}$

This ideology of difference is reflected in the terminology linked to women's rights. In the 1990s, the most widespread term to translate the "gender" concept was shehui xingbie, literally "social difference between the sexes." Over the past few years, xingbie, or "difference between the sexes," is more in use, sidelining the issue of the social construction of the difference and further stressing the differences thought to be natural. The increasing use of the term xingbie in official discourse as well reflects the desire to break with the pre-reform period - especially given the suspicion evoked by the qualifier "feminist," literally "women's rights doctrine" (nüquan zhuyi), an expression echoing asexual feminists of the Mao era. As for "feminism," the use of such terms is also in dispute. In the media and

34. In 2004, the marriage law was revised, and since then domestic violence against women has been outlawed. A specific law on prevention of domestic violence is now under discussion. Since 2003, the Anti-Domestic Violence Network of the China Law Society (Zhongguo faxuehui fandui jiating baoli wangluo,) has proposed several draft laws: Zhonghua renmin gongheguo jiating baoli fangzhi fa fan jia bao wangluo zhuanjia jianyi gao ji shuomin (Law of the People's Republic of China on the Prevention and Punishment of Domestic Violence), Beijing, Anti-Domestic Violence Network of China Law Society, 2010.

35. ACWF, Zhongguo xingbie pingdeng yu funü fazhan baogao (Zhongguo funü lüpi shu) (China Gender Equality and Women's Development Report [Green paper on Chinese women]), Beijing, Social Sciences Academic Press, 2009.

36. Children left behind in rural areas by migrant parents working in cities or special economic zones (liushou ertong) have come to be seen as a major social problem.

37. Programme for the development of Chinese women, 2011-2020, op. cit. See Zhongguo funü fazhan gangyao (2011-2020 nian), www.gov.cn/gongbao/content/2011/content_1927200.htm (consulted on 25 September 2012).

38. Isabelle Attané, En espérant un fils... La masculinisation de la population chinoise (Hoping for a boy: Masculinisation of China's population), Paris, INED, 2010, pp. 133-139.

39. Lisa Eklund, "'Good Citizens Prefer Daughters': Gender, Rurality and the Care for Girls Campaign," in Tamara Jacka and Sally Sargeson (eds.), Women, Gender and Rural Development in China, op. cit., pp. 124-142.

40. Ibid.

41. Tao Jie, "Women's studies in China," Women's Studies Quarterly, Vol. 24, No. 1-2, 1996, pp. $351-$ 363.

42. Tong Xin, "Mainstream Discourse and the Construction of Public Understanding of Women's Employment," art. cit. 
women's press, nüxing zhuyi is preferred, literally "female sex doctrine," rather than nüquan zhuyi, while the ACWF prefers funü quanli, "women's rights," to cut short the debate while fuelling another, as the term funü harks back to traditional Confucian conceptions of women. ${ }^{(43)}$

Contemporary Chinese feminism is understood in this context, and this hybrid reality will now be analysed.

\section{Feminism today: Between state legitimacy and quest for autonomy}

While the ACWF's existence certainly denotes the government's engagement, it also stands as a non-negotiable arena for development of demands for women's rights, as also for research programmes.

\section{All China Women's Federation: An agency for ambivalent action?}

Officially, the ACWF is a "non-governmental organisation" in the Chinese sense, meaning it is under the Party's care. It has consultative status only, with directives on gender equality coming from central authorities since 1949, when the Party grouped the "Women's Bureaus" under the Women's Federation, the name of which has changed from "All China Federation of Democratic Women" (1949) to "People's Republic of China National Women's Federation" (1957) to "All China Women's Federation" (since 1978). At first, the federation was conceived of as an umbrella organ for existing women's organisations. By 1953, it had a staff of 40,000 counting just the levels above counties and municipalities. ${ }^{(44)}$ Based on the Federation's archives in Shanghai and interviews with retired staff, Wang Zheng has focused on women's participation in building a socialist state, examining how their action changed the social scene by highlighting ambiguities not only within the women's movement but also in the Party.

Wang has said that the Women's Federation consists of state feminists. ${ }^{(45)}$ In fact, the federation was for long the only body representing women's causes. In the centralised patriarchal state that is the PRC, laws and policies supposedly favouring women were not always clear in de facto terms until the 1980s. This grey area between official declarations, political motivation, and concrete action does not necessarily imply that it was a simplistic vision of a federation constituting a monolithic block offering women no space for freedom of action. Of course the state used the federation as it did other mass organisations (the youth league and trade unions) to specify the causes, methods, and vision for change, and as masculine protector, ensured women's rights and interests. But the federation has not been reduced to being a mere symbolic representative of a regime that is masculine and acting as protector. Its role is vaguer and richer than might appear, if only because of the discord, disputes, and conflicts of interests and goals among its feminist members.

In the 1980s, the ACWF took a major part in reviving social science research on gender, helping form the first research department on gender in Zhejiang and pursuing an active editorial policy. Besides Women of China (Zhongguo Funü), its own magazine since 1949, the federation has supported others such as Women's Studies (Nüxing yanjiu) and Collection of Women's Studies (Funü yanjiu luncong), which were open to social science scholars. ${ }^{(46)}$ Many gender-related articles appeared in the general press dealing with issues such as the one-child policy and its corollaries (infanticide, late term abortions, and trafficking in women and children).
Besides supporting research (whether highly ideological and controlled or in collaboration with independent academics) and its editorial work, the federation has also sought to adjust to socioeconomic change, affirming its position in defending women's rights without, however, questioning the state's role. Women from the ACWF regularly take a stand, especially through the press as well as with concrete action, to defend women's jobs threatened by reforms, and to denounce the working conditions of migrants, discrimination against women in the matter of layoffs in urban areas, trafficking in women and girls, and domestic violence. ACWF officials also organise training and refresher courses in major cities. Such activities would have been deemed subversive until 1978, but enjoy state approval now. ${ }^{(47)}$

The World Conference on Women (Beijing, 1995) was a major breakthrough for feminist action. The ACWF no longer holds the official monopoly on action for women. NGOs have managed to stage effective action: three of the most famous and active ones are: "Anti-Domestic Violence," "Gender and Development," and "Women and Gender Studies." (48) As in other national contexts, there is a diversity of Chinese feminists (state feminists and more or less independent feminists) who occupy various positions in the "women's cause arena." (49) At times they may be in mutual opposition, defending divergent interests, but they also mobilise jointly, depending on the contexts and challenges. Ideas and competences circulate between the ACWF feminists, the militants from other non-governmental organisations with no direct links to the party, and academics and researchers working on gender, with real collaborations existing. Interestingly, these diverse manifestations of feminism can also be seen in the protagonists of these movements, who may take part in militant action independent of state directives while at the same time occupying official positions.

\section{Production of a new discourse on gender}

Production of discourse on women takes place in both political and cultural contexts in China. First of all, before the World Conference of 1995, the fact that since the second half of the 1980s, women's studies (outside social sciences departments) were carried out by Party schools and academics who were not necessarily sociologists typified Chinese social sciences' history as a whole (under severe Party supervision from 1953, and banned until the 1980s). Because of this, paradoxically, when gender or equality between the sexes did not appear as secondary or irrelevant, the problems of gender relations met with resistance in the Chinese world, as it seemed to be linked to state or Party ideology promoting equality between the sexes

43. Tani Barlow, "Politics and Protocol of Funü: (Un)making National Woman," in Christina K. Gilmartin, Gail Hershatter, Lisa Rofel, and Tyrene Whyte (eds.), Engendering China. Women, Culture, and the State, Cambridge (MA), Harvard University Press, 2004.

44. Wang Zheng, "'State Feminism'? Gender and Socialist State Formation in Maoist china," art. cit.

45. Wang Zheng, "'State Feminism'? Gender and Socialist State Formation in Maoist china," art. cit; Wang Zheng, "Le militantisme féministe dans la Chine contemporaine" (Feminist activism in contemporary China), Travail, genre et sociétés (Work, gender and societies), No. 23, 2010, pp. 103122.

46. See also Xingbie yanjiu wenku (Gender study network), www.genderstudy.cn/html/category/9221.htm (consulted on 25 September 2012).

47. Louise Edwards, "Issue-based Politics: Feminism with Chinese Characteristics or the Return of Bourgeois Feminism?", in David S. G. Goodman (ed.), The New Rich in China. Future Rulers, Present lives, London/New York, Routledge, 2008, pp. 201-212.

48. Wang Zheng, "Le militantisme féministe dans la Chine contemporaine," art. cit.

49. Laure Bereni, "Quand la mise à l'agenda ravive les mobilisations féministes. L'espace de la cause des femmes et la parité politique (1997-2000)" (When agenda setting revived feminist mobilisations: The arena for women's cause and political parity [1997-2000]), Revue française de science politique (French Political Science Review) Vol. 59, No. 2, 2009, pp. 301-323. 
Moreover, a scientific, cooperative, and mediatic discourse on women and gender relations has emerged in a context of economic modernisation and rupture with Maoist thought. Scientific modernity as conceptualised in the West has been seen as a key to dismantling Maoism in theories, research programmes, and teaching. This explains what American feminists call gender turn in the 1990s - challenging and then relegating the class paradigm in favour of gender. For concerned parties, gender seemed to be the means for challenging hierarchies and power relations of domination and for studying social change without openly questioning the Chinese state. Paradoxically, academics have been the most reticent and have taken the longest to engage in such analysis, behind the sectors of associations and the media.

The ACWF has lent strong encouragement to the production of historic studies on women. The movement has gradually grown. In the 1980s, some historians wanted to be rid of the shackles of Party historiography centred on class struggle, peasant revolt, and revolutions (mainly French, Russian, and Chinese). Social and cultural history and women's history became fashionable. A confused scene emerged in China between women's history - pursued from a masculine viewpoint by both men and women, with no critical perspective and blind to the gender problematic - and the history of gender relations - pursued by feminist personalities, mostly women.

In the final analysis, the production of academic discourse on gender issues in China stems from the emergence and development of a new social history from the 1990s onwards, ${ }^{(50)}$ and from the opening out to Western feminist scholars as well as the pursuit of gender studies in China on the part of Western feminist scholars, especially from the Anglo-Saxon world. (51) Social history has undergone a renewal in terms of its aims, sources, and methodology. Thus, women's history has soared alongside studies on ethnic minorities and on what may be termed "China's lower classes." A veritable historiographic reflection has taken place. The resulting current of women's history has led to the revisiting of Chinese history over many centuries - many millennia, even - especially taking into account ethnic origins. To cite a concrete example, it was (re)discovered that the practice of feet-binding was limited to the dominant Han ethnicity and there, too, only to the privileged social milieux. Throughout history, no ethnic minority in China bound women's feet for aesthetic reasons or to limit their autonomy; in fact, even among the Han, the poorest and peasant families did not take to the practice, which would have deprived them of a precious female worker.

\section{Key figures caught between independence, marginality, and collaboration}

Academics and scholars writing on women are a reflection as well as a product of this Chinese feminist context and its evolution within academia and elsewhere. Two figures, among others, symbolise this feminist history.

\section{Li Xiaojiang}

No discussion of Chinese studies on women can exclude a mention of $\mathrm{Li}$ Xiaojiang, born in 1955. She teaches in the Chinese department at Zhengzhou University, where she also holds seminars at the Women's Studies Research Centre. She came to prominence in 1983 with the publication of an article on humanity's progress and women's liberation. The article kindled the Party's ire, but she won appreciation from a large section of academia. In it she said the configuration and evolution of gender relations took precedence over and transcended class relations.
Li was also the first to perceive the danger economic reforms posed to Chinese women's condition. That is why she called for women's collective awareness. Also in 1983 she founded the first independent association for women's studies (Funü Xuehui). That same year, the association organised multi-disciplinary conference on women's studies. In 1987, the first women's studies centre in China was set up in Zhengzhou University (Zhengzhou daxue funüxue yanjiu zhongxin). This was replicated at Changsha and the Foreign Languages Institute in Beijing. A year later, "salons" (shalong) made up of diverse groups mushroomed in the universities of Fudan, Beijing, Hangzhou, Wuhan, Jilin... The 1989 events, far from cutting them short in full flow, lent these salons great dynamism. Women's studies centres proliferated in universities. Peking University (Beida) offered two courses in 1989-1990: one on the history of Chinese women (in the history department) and another a critical study of Western feminists (in the literature department).

These departments actively collect the proceedings of conferences and published catalogues of various publications related to women's studies. Beida and Zhengzhou University have undertaken studies on women's oral history. In 1993, Zhengzhou went further by setting up a university for women. At Li's instance, construction of a women's history museum began in 1991. Last but not least, Li heads a publishing house (Funü Yanjiu Congshu) that puts out works by academics pertaining to demographic problems, the economy, sexuality, and legal issues.

\section{Chen Yiyun, or new voices in women's studies}

Chen Yiyun represents an interesting case for understanding the conditions under which discourse on women takes place outside the groves of academe and independent of the Party line, even if she was initially part of it, as are many other academics.

Chen's career path is unique: she grew up in the 1950s, had social worker training, and like Li Xiaojiang was a researcher, at the Chinese Academy of Social Sciences in Beijing, for some years. She did not suffer from the crackdown on social sciences during the Cultural Revolution when she was doing field work on problems of women and families. She was then focusing on issues such as prostitution and sexually transmitted diseases as well as problems stemming from changes in marriage and the family unit in urban areas. Her main contribution has been to analyse the repercussions of economic reforms on people's attitudes towards marriage and family and changing lifestyles. What role have women played in China's modernisation drive? What pressures have they faced? Her hypothesis has been that the fate and condition of all Chinese women are irresistibly linked to the matrimonial and family situation. That is bound up with every Chinese woman's fate.

In the early 1980s, Chen took part in a survey of women, but was dissatisfied with the results. The survey relied on questionnaires but the methodology was disputed. Chen soon emerged as a pioneer in developing research on women and in introducing new tools. While challenging the Chinese questionnaire method, she offered a series of reflections on the inadequacies of Western methods in China. She has warned Western researchers against

50. Wang Shuo, "The 'New Social History' in China: The Development of Women's History," History cooperative, Vol. 39, No. 3, May 2006, pp. 1-8, www.historycooperative.org/journals/ ht/39.3/wang.htlm (consulted on 25 September 2012).

51. Christina K. Gilmartin, Gail Hershatter, Lisa Rofel, and Tyrene Whyte (eds.), Engendering China: Women, Culture, and the State, Cambridge (MA), Harvard University Press, 1994; Harriet Evans, Women and Sexuality in China, New York, Continuum, 1997; Delia Davin, Chinese Lives: An Oral History of Contemporary China, New York/London, Pantheon/Macmillan, 1988. 
biases in sociological surveys in China, noting that the surveys always show what is socially wished for rather than what people feel or how they act in reality.

Demonstrating the relevance and need for a new method, she fell back on her own experience (novel in China and made possible by the country's opening). Alongside her academic activities, Chen presented radio and television programmes in the late 1980s, letting women air their difficulties. She offered family therapies and conducted field studies in provinces. From these various practices, Chen highlighted four structural factors in research on women: 1) the diversity of realities depending on social differences and geographic disparities; in a research domain in which the tendency is to speak of women's reality as homogeneous, the position she took was eminently novel; 2) the ACWF has to be given its due place, which does not mean putting it on a pedestal; 3 ) the development of an anthropological method is necessary; 4) international exchanges on women's issues are one of the bases of success, even if to some extent women's studies in China need to be Sinified.

Chen was no exception. While opening the path to a certain form of more "anthropological" research on women, she has been part of a circle of scholars who challenge the supremacy of statistics in social sciences, communicate with the West, and seek a method amenable to responding to China's specificity and expanse. At the NGO meetings paralleling the World Conference of Women in 1995, it seemed that Chinese scholars had begun enjoying greater autonomy compared to the past, lending them great vitality. This is the most striking aspect, especially when the Chinese production on the subject is compared with that from the West.

To complete the picture, transnational Chinese feminists such as Wang Zheng must be mentioned. In the second half of the last decade, the feminist militant and academic founded and co-directed the Joint Institute for Gender Studies at Fudan University and the University of Michigan, after having finished her thesis in the United States and holding the post of associate professor at the University of Michigan. These feminists occupy a special place in contemporary Chinese feminism, influencing it with their dual education and networks, Chinese and international.

\section{Conclusion}

The central government's plan to promote the rule of law has served the cause of equality between men and women to the extent that since the 1990s, the regime's leaders have come up with numerous laws to try and counter discriminations against women. While the application of these laws remains patchy, as indeed it does in most countries, it would appear that the existence of a governmental organisation such as the ACWF is not merely indicative of an official stranglehold on demands for equality. In fact, it has allowed for the emergence of a forum for discussion and debate, ushering in not only the development of gender studies in China but also the emergence of feminist networks.

The challenges and vagaries of Chinese feminism may be seen in the lexical context of the ongoing debates in China. These philological debates reflect a rich and complex but incomplete history of ideas, between a desire to break with the West and calls for a Chinese modernity. The latter is coming about by shunning Maoist ideology and boosting economic reforms as well as opening out to international feminist movements, of course not without ambivalences. Chinese feminism today is a product of both its ancient and recent history, and is linked to as well as breaking away from West- ern feminism, with which dialog has increased since 1995. In this sense, the study of contemporary Chinese feminism constitutes an ideal entry point for studying the political and social issues of modernity, power, and counterpower touched on in this paper. It also challenges the Western conception of gender, stressing the fluidity of gender identities as it helps account for their particular anchoring, and building on the biological and scientific conception of the differences that emerged in eighteenth century Europe.

\section{Translated by N. Jayaram.}

I Tania Angeloff is Reader in Sociology at the University of ParisDauphine, Centre for Interdisciplinary Research in Social Sciences.

Bureau P 408 ter, Université Paris-Dauphine, Place du Maréchal de Lattre de Tassigny, 75775 Paris cedex 16, France (tania.angeloff @dauphine.fr).

Marylène Lieber is Associate Professor of Sociology, Institute for Gender Studies, University of Geneva.

Bureau 5360, Uni Mail, Boulevard du Pont d'Arve 40, CH - 1211 Genève 4, Suisse (marylene.lieber@unige.ch). 